\title{
Codification of Indonesian Culinary: Critical Analysis of Traditional Food
}

\section{Ari Fadiati, Mariani, and Sachriani}

Culinary Arts Vocational Education Study Program, Faculty of Engineering, State University of Jakarta

\section{Abstract}

Soto is one of the traditional dishes consumed by almost all Indonesian people. A variant of Soto in this country causes Indonesia to be called the land of 1001 Soto. The results revealed that Soto consisted of Clear Soto and Thick Soto. The structures are: (1) white paste seasoning of Soto; (2) typical seasoning of Soto which is a must in Indonesian Soto; (3) typical seasoning in each Soto that adds to each Soto and makes them typically; (4) liquid; (5) content material; (6) condiment; (7) crackers or chips; (8) condiment; (9) other complement. According to results, the majority of Soto used complete white paste seasoning (66.6\% in Clear Soto and $92.8 \%$ in Thick Soto); typical

Corresponding Author:

Ari Fadiati

arifadiati@yahoo.com

Received: 11 January 2019 Accepted: 14 February 2019 Published: 25 March 2019

Publishing services provided by Knowledge E

(c) Ari Fadiati et al. This article is distributed under the terms of the Creative Commons

Attribution License, which permits unrestricted use and redistribution provided that the original author and source are credited.

Selection and Peer-review unde the responsibility of the 3rd ICTVET 2018 Conference Committee.

\section{G OPEN ACCESS} seasoning of Soto used complete seasoning (23.3\% in Clear Soto and $7.1 \%$ in Thick Soto). The majority of seasoning used galangal, lemongrass, coriander, and bay leaves; liquid used chicken stock and beef stock in case of Thick Soto adding coconut milk. The content material is groups of noodles, animal and vegetable protein, vegetables, and processed food. Fried onions were used as a condiment. Crackers or chips were dominated by Emping. Various condiment and other complementary ingredients such as various oranges and raw pickles were served separately. In conclusion, 77.2\% of data from recipe books with real conditions are very suitable.

Keywords: codification, the structure of Indonesian Soto, the seasoning used

\section{Introduction}

Indonesia has 1340 various tribes [8]. Each tribe has its own culture, so each region has its food characteristics. According to Hadisantosa in FG Winarno et al [18], regional foods or traditional foods consumed by ethnic group society and a specific region, processed by recipes known to society. The ingredients came from local sources and had a taste which is relatively by the tastes of local society. Based on lexical meaning, traditional foods have a relationship between food and the specific tradition of society. William Wongso [14] said that there is no Indonesian food, but there is a collection of various regional dishes within the territory of Indonesia. Each ethnicity has its peculiarities even in the same dish. Food used as a unifying nation or a harmonious relationship between 
ethnic groups in Indonesia, even as a nation branding in the dining table diplomacy. It has an impact on the country's economy and popularity as has been done by Thailand, Japan, Korea and others. Many things that must be prepared to be used as a nation branding need to be made an effort to (1) increase the way of serving traditional food by utilizing new technology equipment and presented in an exciting manner; (2) increase the quality of traditional food both organoleptically, nutritional quality, sanitation and hygiene and the environment; (3) increase the economic value of traditional food; (4) increase efforts to expand traditional food to other regions; and (5) increase business owner's capital of traditional food.

Soto is one of the traditional dishes consumed by almost all Indonesian people. A variant of Soto in this country causes Indonesia to be called the land of 1001 Soto. Considering the variety of traditional food recipes, especially Soto, it is difficult to use as a reference in formulating formulas and processing them. As a first step, it is necessary to compile the codification of Indonesian culinary, especially Soto, by analyzing the structure of ingredients, seasonings, making techniques and presentation. Codification means the classification of Indonesian Soto.

\section{Methods and Equipment}

\subsection{Methods}

This study was a literature study that obtained from various sources such as journals, books, archives, magazines, articles, documentation, internet, libraries, and documents that are relevant to the problems studied. The collection of literature related to Indonesian Soto followed by the selection of literature that fitted the criteria, namely: listed author, publisher, details of recipes, liquids, ingredients, condiment, crackers or chips, condiment and other supplementary ingredients. One literature fulfilled the requirements of Soto recipe and followed by tabulation and triangulation though in-depth observation and interviews with Soto sellers and informants who came from the Soto region and competent to process them in Jakarta - Bogor - Depok - Tangerang - Bekasi (Jabodetabek). The selection of Soto stalls or restaurants sold typical Soto from their region. Both the seller and owner came from the Soto region. Customers came from the Soto region. The triangulation result continued to the codification of the Indonesian culinary, especially Soto. 


\section{Results}

\subsection{Clear Soto}

\subsection{Thick Soto}

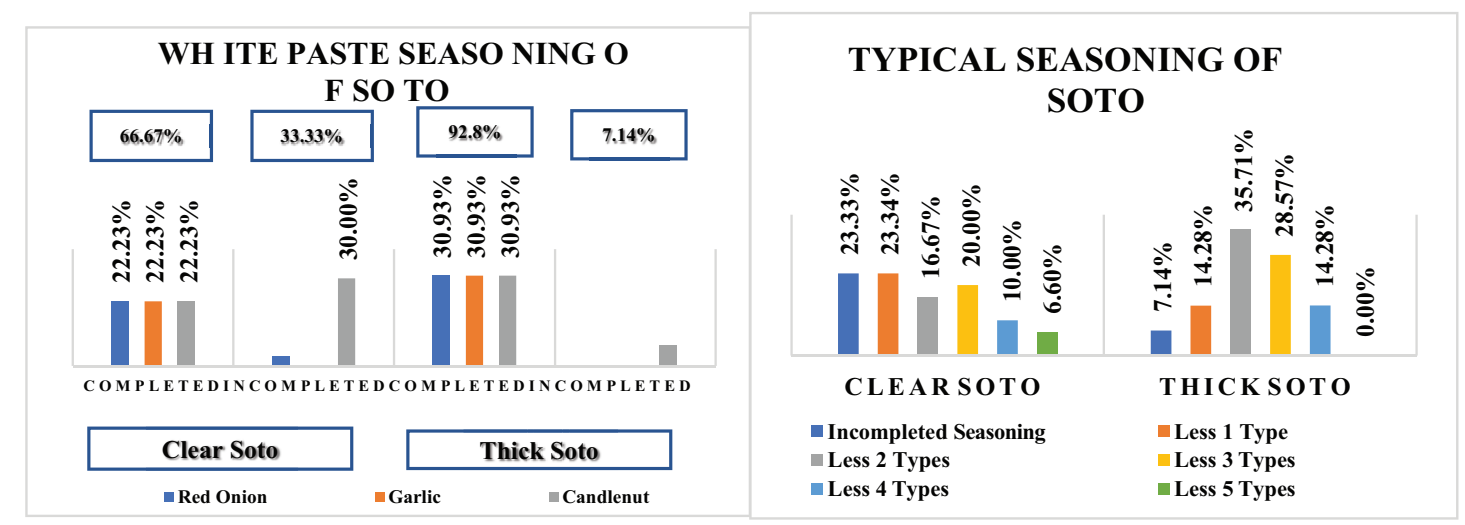

Figure 1: Histogram of white paste seasoning of Soto (a) and typical seasoning of Soto (b).

A white paste seasoning of Soto included red onion (Allium Cepa), garlic (Allium Sativum) and candlenut (Aleurites Moluccana). Typical seasoning of Soto used lemongrass, coriander, galangal, ginger, lemon leaf, Salam leaf, and pepper. Liquid stock used chicken stock, and coconut milk for thick Soto. The content material used animal protein, mostly meat and chicken, vegetables such as cabbage, sprouts, bean sprouts, yellow noodles, and a group of vermicelli. The condiment is predominantly using fried onions. Crackers or chips used Emping. A chili sauce used is boiled chili sauce and fried chili sauce. Other complimentary ingredients used fresh pickles and many oranges. A staple food for Soto is white rice, Ketupat, and rice cake, while Burasa only used in some types of Soto.

Completed white paste seasoning used by 20 of 30 clear Soto (66.6\%) and 13 of 14 clear Soto (92.8\%). The white paste seasoning did not use candlenut by 9 of 30 clear Soto (30\%) and 1 of 14 Thick Soto (7.1\%). Completed typical seasoning of Soto used 7 of 30 clear Soto $(23.3 \%)$ and 1 of 14 thick Soto murky (7.1\%). The typical seasoning of Soto did not use lemon leaf, pepper and ginger. It depends on the type of Soto processed in the form of seasoning and herbs used. If Soto gets influence from Middle Eastern and Indian cultures, the seasoning is more varied. Whereas, if Soto gets influence from China, the use of garlic is predominantly in white paste seasoning. A triangulation result showed that $77.2 \%$ of data from recipe books with real conditions are very suitable. 


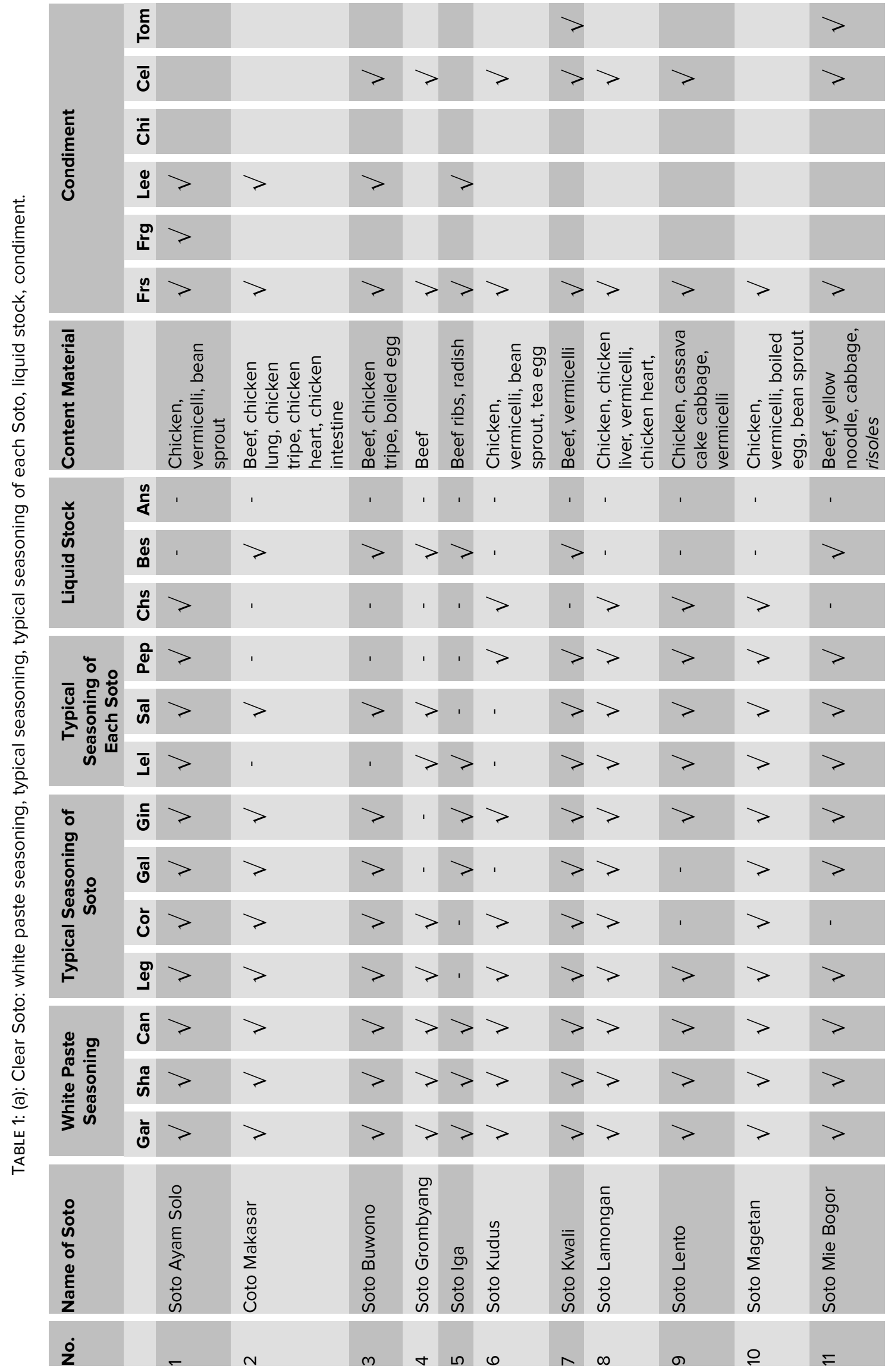



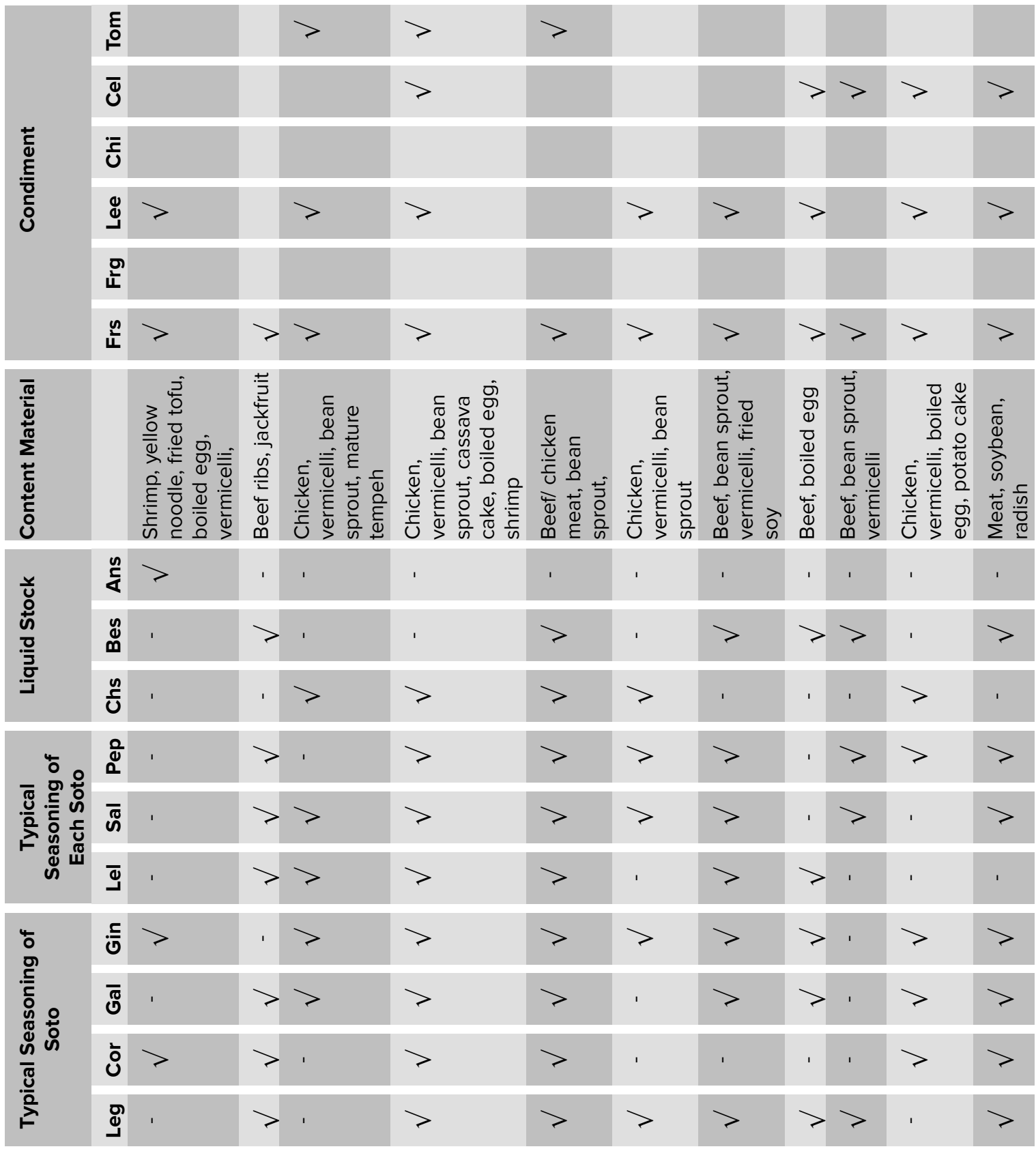

\begin{tabular}{|c|c|c|c|c|c|c|c|c|c|}
\hline \multirow{3}{*}{ 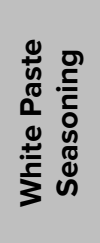 } & & ర్ $>$ & $>>$ & $>$ & $>$ & $>$ & $>$ & $>>$ & ' \\
\hline & & $>$ & & $>$ & $>$ & $>$ & $>$ & $>$ & $>$ \\
\hline & 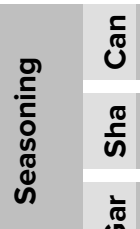 & $>$ & & $>$ & $>$ & $>$ & $>$ & $>$ & $>$ \\
\hline
\end{tabular}

\begin{tabular}{|c|c|c|c|c|c|c|c|c|c|c|}
\hline 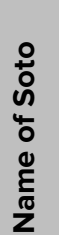 & $\begin{array}{l}0 \\
\frac{1}{0} \\
\frac{\pi}{0} \\
0 \\
0 \\
\sum_{0}^{2} \\
0 \\
0 \\
0\end{array}$ & 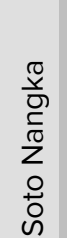 & $\begin{array}{l}E \\
\bar{D} \\
0 \\
0 \\
0 \\
0 \\
0 \\
0 \\
0 \\
0 \\
0\end{array}$ & 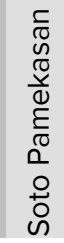 & 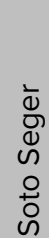 & $\begin{array}{l}3 \\
\frac{3}{0} \\
0 \\
0 \\
0 \\
0\end{array}$ & & & 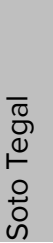 & 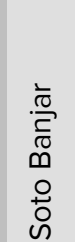 \\
\hline í & $\simeq$ & $\underline{m}$ & $\Xi$ & $\stackrel{\llcorner}{\Omega}$ & $\underline{\varphi}$ & 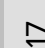 & & & & \\
\hline
\end{tabular}



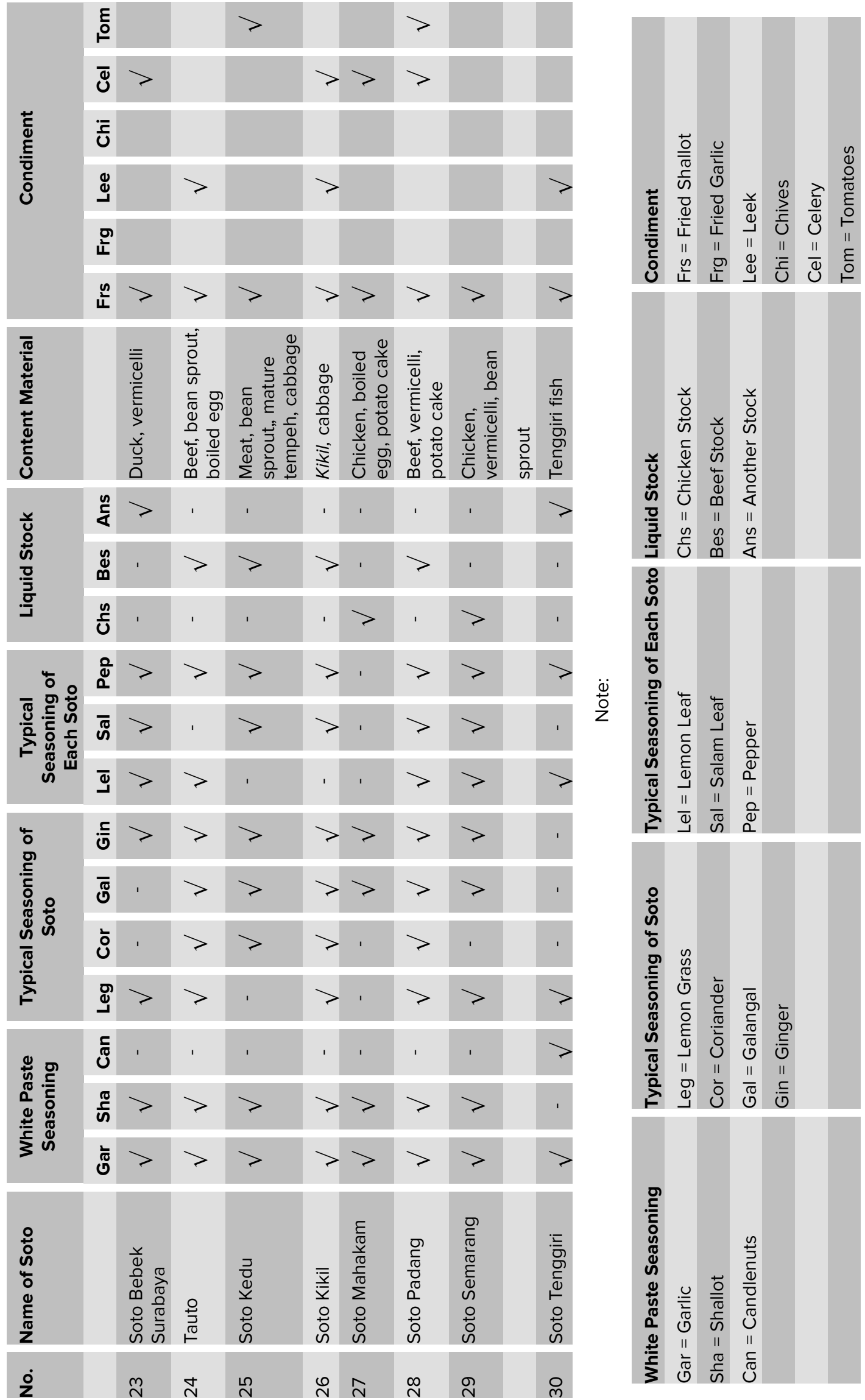

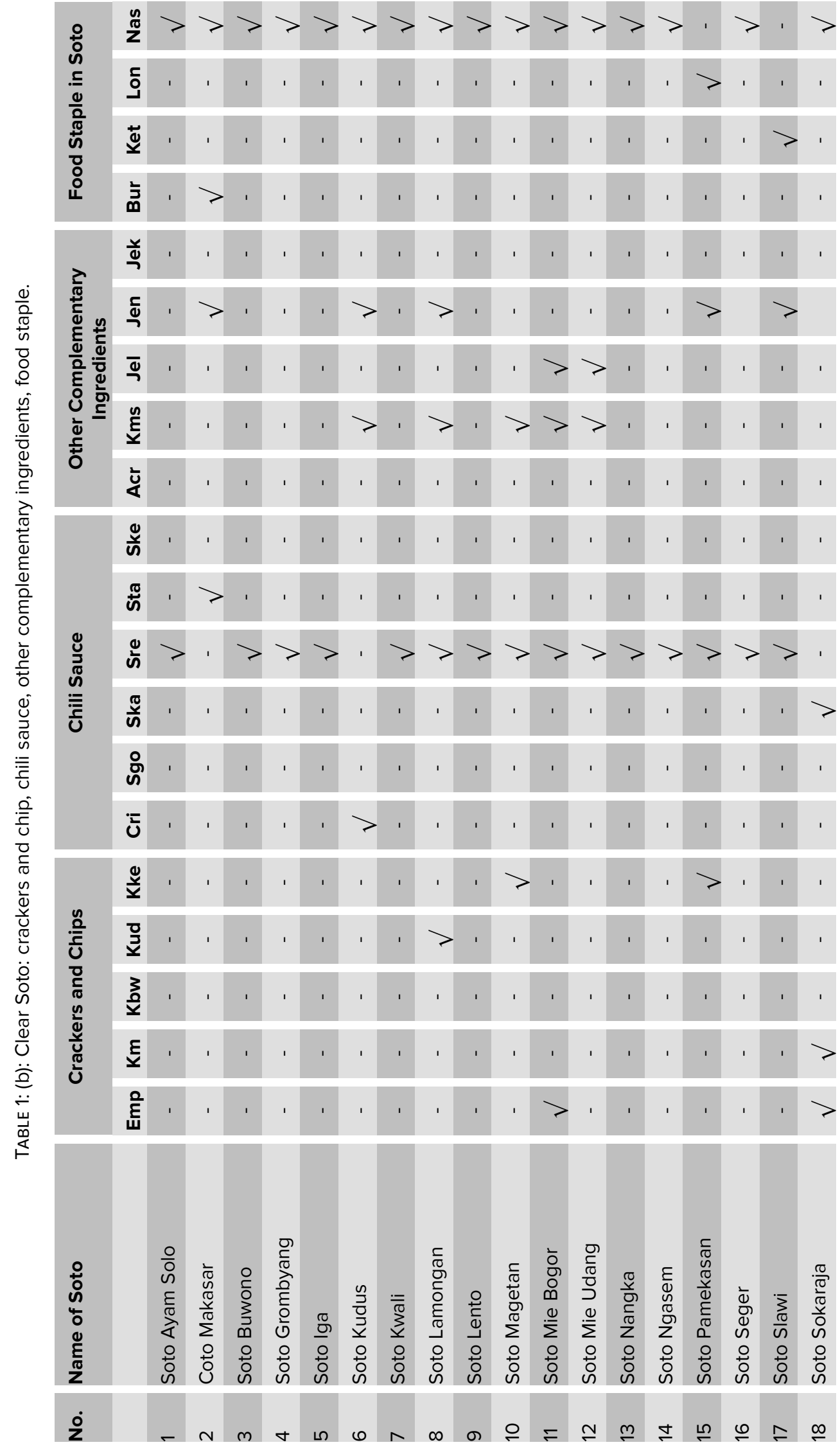


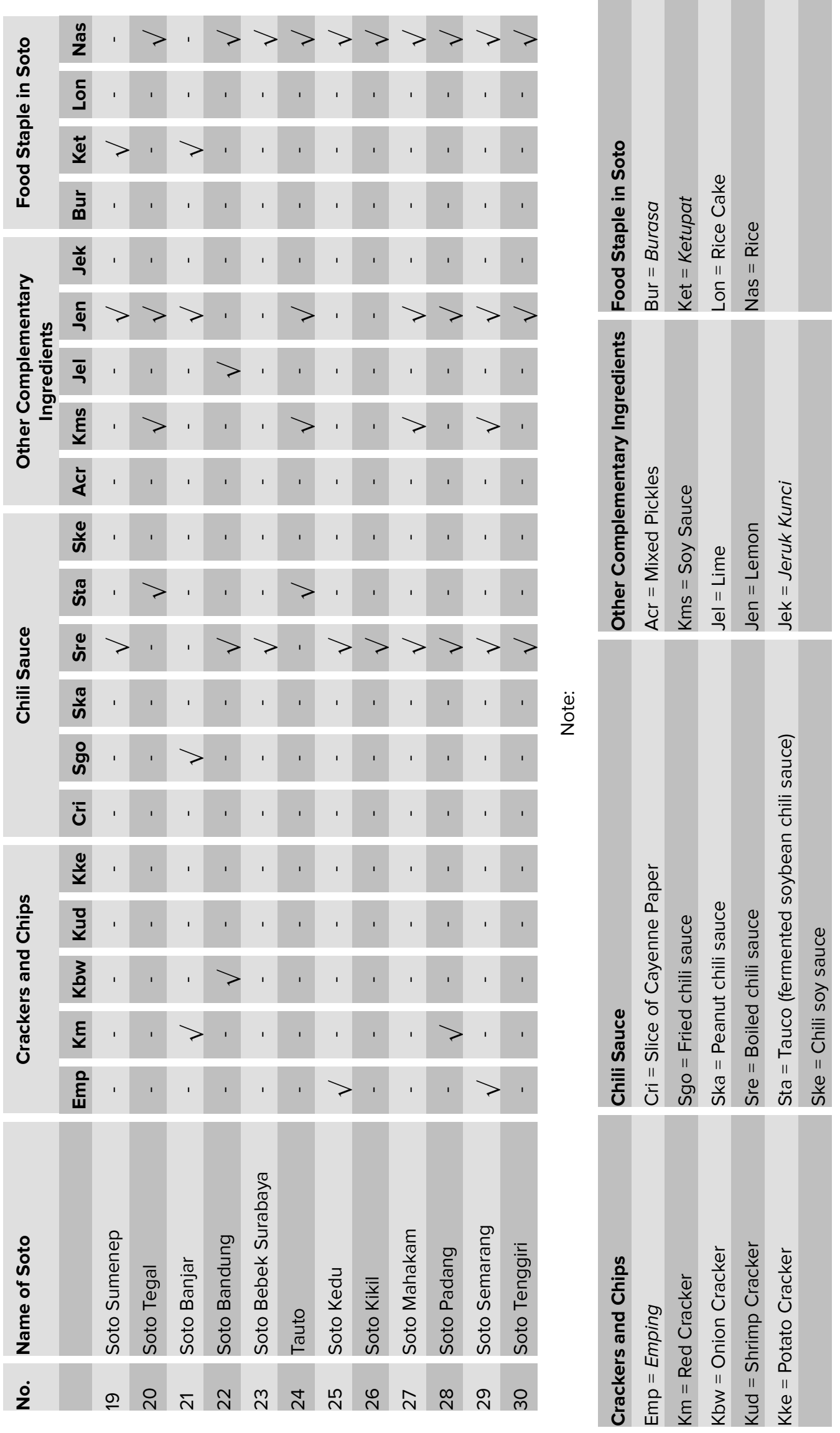




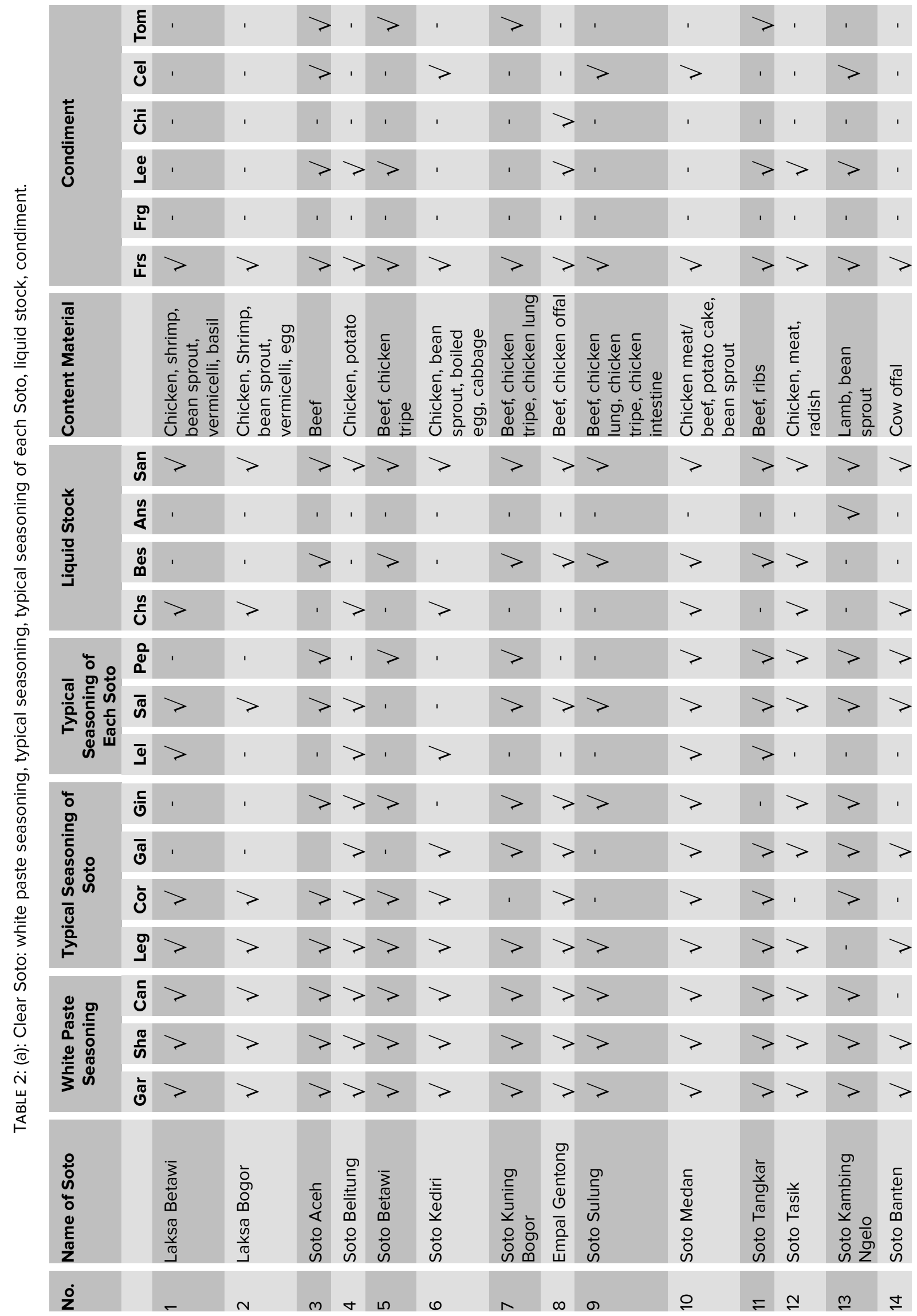




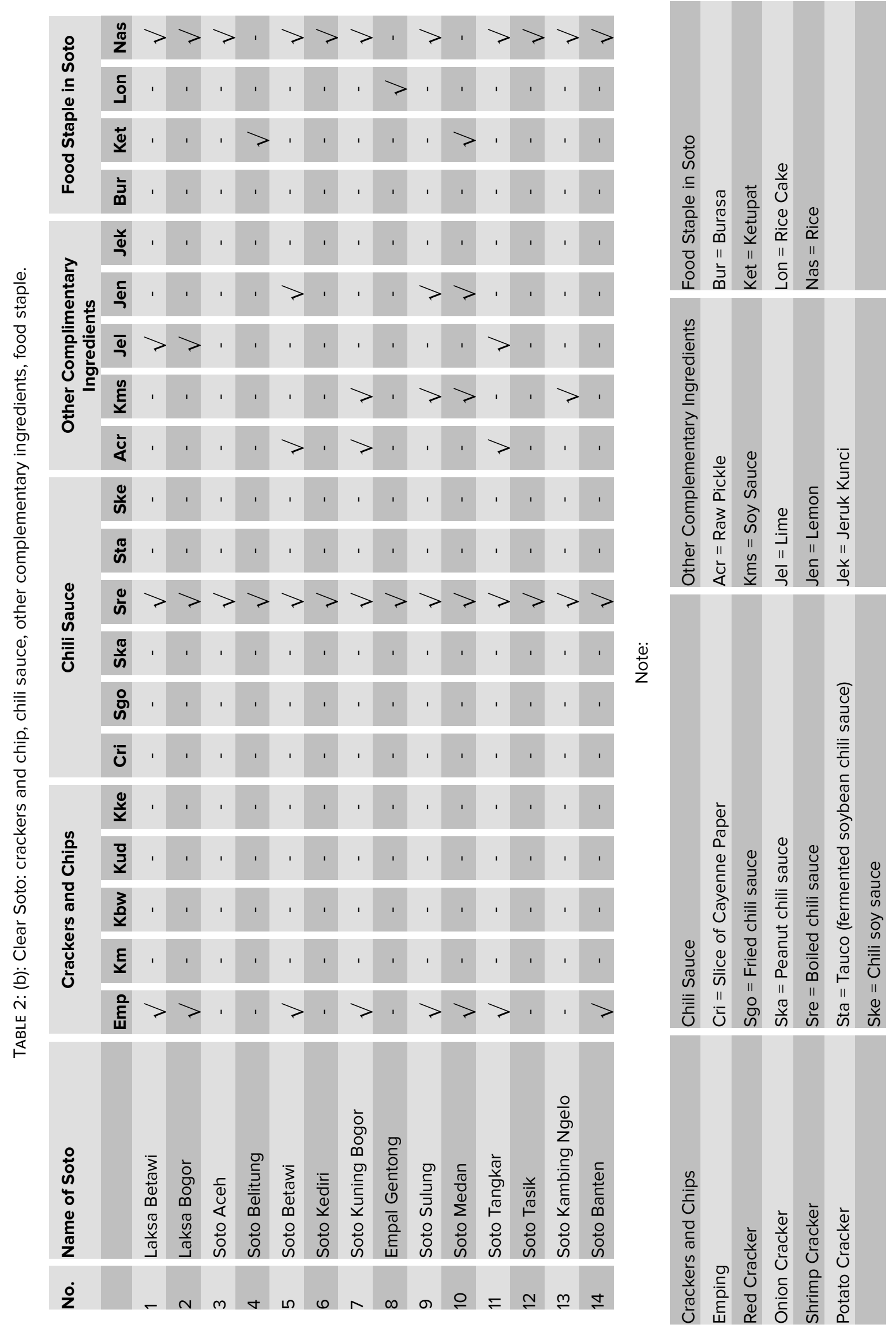




\section{Discussion}

In clear Soto, candlenut, that did not use complete white paste seasoning, serves as a $30 \%$ savory flavor, because it used another seasoning that also functions as a savory flavor like Tauco in Soto Tauco, potato cakes in Soto Padang, duck meat with high fat in Soto Bebek Surabaya and peanuts in Soto Mahakam. Also, there were types of Soto that wanted the results to be clear, not strong- flavored, and not too savory like Soto Bandung, Soto Kikil, Soto Semarang, and others. In thick Soto, the majority used complete white paste seasoning (92.8\%) because they wanted a thick and delicious result. For typical seasoning of Soto majority did not use 2-3 types (22.2\% each seasoning) which dominated by coriander, ginger and pepper. It was due to the use of condiment in typical seasoning. Each typical seasoning of Soto differed one Soto course and other Soto course. In thick Soto, adding coconut milk made Soto more savory than clear Soto. The content material of each Soto generally adjusted to the results of food in their respective regions.

\section{Conclusion}

With the increasing quality of Indonesian Soto, this course is not only consumed by the local society as well as the Indonesian people, but also it can also be served as an international course on soup course group about the choice of Soto course, amount of seasoning, cut shaping and serving. In conclusion, Soto can use in various dining table diplomacy events that can use as a promotion as a nation branding.

\section{Funding}

This research was funded by the Badan Layanan Umum (BLU) Faculty of Engineering, State University of Jakarta.

\section{Acknowledgement}

The authors would like to thank their colleagues for their contribution and support to the research, and also to all the reviewers who gave their valuable inputs to the manuscript and helped in the completion of it. 


\section{Conflict of Interest}

The authors have no conflict of interest to declare.

\section{References}

[1] Fadiati, Ari; Mariani; Efrina. (2009). RPKPS Pengelolaan Makanan Nusantara. FT UNJ: Program Studi Tata Boga.

[2] Ganie, Suryantini N. (2003). Upa Boga di Indonesia, Ensiklopedia Pangan dan Kumpulan Resep. Jakarta: Gaya Favorit Press.

[3] Gardjito, Hurdijati. (2013). Bumbu, Penyedap, dan Penyerta Masakan Indonesia. Jakarta: Gramedia Pustaka Utama.

[4] Gardjito, Hurdijati; Rhaesfaty; Swastika. (2017). Profil, Struktur, Bumbu dan Bahan dalam Kuliner Indonesia. Yogyakarta: Gadjah Mada University Press.

[5] Gardjito, Murdijati; Eni Harmayani; Umar S. (2018). Makanan Tradisional Indonesia Seri 3. Yogyakarta: Gadjah Mada University Press.

[6] Harmayani, Zni; Umar S; Murdijati G. (2017). Makanan Tradisional Indonesia Seri 2. Yogyakarta: Gadjah Mada University Press.

[7] Marwanti. (2000). Pengetahuan Masakan Indonesia. Yogyakarta: Adicita Karya Nusa.

[8] Na'im, Akhsan; Hendry Saputra. (2011). Kewarganegaraan, Suku Bangsa, Agama Dan Bahasa Sehari-Hari Penduduk Indonesia Hasil Sensus Penduduk 2010. Jakarta: Badan Pusat Statistik

[9] Rachman, Fadly. (2016). Jejak Rasa Nusantara, Sejarah Makanan Indonesia. Jakarta: Gramedia Pustaka Utama.

[10] Santoso, Umar; Murdijati G; Eni Harmayani. (2017). Makanan Tradisional Indonesia Seri 1. Yogyakarta: Gadjah Mada University Press.

[11] Sigor, Edi; Ernawati. (2004). Buku Pintar Masakan Daerah. Jakarta: Belaprasta.

[12] Skrobanek, Deflef; Suzanne Charle; Gerald Gay. (1988). The New Art of Indonesian Cooking. Singapore: Time Editions.

[13] T, Yulia; Astuti Utom. (2008). Resep Masakan Khas Nusantara dari 33 Propinsi. Jakarta: Gramedia Pustaka.

[14] Tajudin, Qaris; Seno Joko Suyono; Purwani Diyah Prabandaari et al. (2015). Antropologi Kuliner Nusantara Ekonomi, Politik dan Sejarh Di Belakang Bumbu Masakan Nusantara. Jakarta: PT Gramedia 
[15] Tim Dapur Demedia. (2010). Kitab Masakan, Kumpulan Resep Sepanjang Masa. Jakarta: Demedia Pustaka

[16] Tim Komunitas Bumbu. (2016). Mustika Rasa, Resep Maksakan Indonesia Warisan Sukarno Cetakan kedua. Depok: Komunitas Bumbu.

[17] Ulung, Gagas; Dee Rona. (2014). Jejak Kuliner Arab di Pulau Jawa. Jakarta: Gramedia Pustaka Utama

[18] Winarno, FG; Emma S. Wirakusumah, Dedi Fardiaz dkk. (1999). Kumpulan Makanan Tradisional I. Jakarta: Departemen Pendidikan dan Kebudayaan

[19] Winneke, Odila; Rinto Habsari. (2001). Kamus Lengkap Bumbu Indonesia. Jakarta: Gramedia Pustaka Utama 